\title{
Port Revenue Performance and Economic Growth: The Nigerian Ports Authority Experience, 2010-2019
}

\author{
Richard C. Osadume $^{1 *}$ and Edih O. University ${ }^{1}$ \\ ${ }^{1}$ Nigeria Maritime University, Department of Marine Economics and Finance, Delta, Nigeria; \\ Email: Richard.osadume@nmu.edu.ng,oweilade123uni@gmail.com
}

\section{*Corresponding Author: Richard C. Osadume}

Received: 3 July 2020; Revised: 20 July 2020; Accepted: 29 July 2020; Published: 30 November 2020

\begin{abstract}
The Study examined Port Revenue Performance and Economic Growth: The Nigerian Ports Authority Experience, 2010 to 2019. The objective of this study is to examine the effect of Port Revenue Performance on Nigeria's economic growth by critically evaluating the Nigerian Ports Authority Performance. The neoclassical growth theory was employed in the study and the Nigeria Ports Authority was chosen as its sample, covering the period from 2010 to 2019. The study used secondary time series data sourced from the Nigeria Ports Authority and the National Bureau of Statistics and used the ordinary least square regression and the Engle-Granger co-integration to test the variables at the $5 \%$ level of significance. The findings showed that total revenue to gross registered tonnage had positive and significant effect on economic growth while operating surplus to operating revenue showed a negative but significant effect and operating surplus to cargo throughput showed insignificant effect; there was no co-integration between the variables. The study concludes that Port revenue performance affects economic growth in the short-run only, and it recommends amongst others that policy makers should formulate appropriate and implementable regulatory framework that will address infrastructural deficits at the ports and stimulate increased utilization by major foreign vessel companies.
\end{abstract}

Keywords: Revenue generation, ports performance, Nigeria ports authority, cargo tonnage, gross registered tonnage

\section{Introduction}

Economic growth and development of any country largely depends on the performance metrics of its international trade and investments because no single country can exist on its own. Domestic and foreign trades will be difficult without efficient transportation system to convey marketable goods and maritime business presents opportunity for the transportation of large volume of cargo. Records have shown that over $80 \%$ of the volume of international trade is transported by sea. This necessitate the importance of ports operations to countries endowed with coastal features 
[1]. Ports have been seen as catalysts and gateways for economic growth and development [2-4]. Scholars and Maritime experts have noted the need to private port operations as major reform in the maritime sector in Nigeria pointing out that, with globalization, the government alone cannot effectively manage a modern seaport successfully $[5,6]$. The performance of ports in the generation of revenue among other contributions to national economy hinges on several factors. The problem of ports capacity and congestion, high level of demurrage, competitive structures, lack of facilities, level of investment and management deficit are issues confronting the smooth operation of ports activities, thereby stifling the quantum of revenue generation to the nation`s treasury [7-9].

These quantum of studies have not agreed on the effect of revenue performance of an ideal port authority on economic growth, and presents a gap to be resolved by this study. The main objective of this study is thus, to determine whether revenue performance of port authorities affect economic growth of their countries, and the specific objective of this study is to evaluate the effect of Nigeria port authority revenue performance on the economic growth of Nigeria. Such a study attempts to answer the question such as - Does Port revenue performance affect a country's economic growth? It is expected that answer to such a question apart from adding to empirical literature on subject, will also assist maritime policy makers to make effective ports administration and management decisions. The hypothesis to such a research question will usually be in the null form;

$\mathrm{H}_{0}$ : Nigeria Port Authority Revenue Performance does not affect the economic growth of Nigeria. Hence, this study will consider; 1. Introduction, 2. Data and Methods, 3. Results, 4. Discussions, 5. Conclusion.

\subsection{Literature Review}

\subsubsection{Evolution of Ports Authorities}

Shipping businesses in most countries are usually coordinated and regulated by their respective ports authorities. These Ports authorities could be described as organizations responsible for the management, development and regulation of port activities. These institutions perform variety of functions, with different terms of business operations and governance structure [10-15]. Ports authorities perform three basic functions ranging from, i) Landlord function; ii) Regulator function; iii) Operator function [16]. The landlord function entails such activities as competition between port structures. The regulator function involves activities relating to the creation and implementation of benchmark standards for activities in the port while the operation function entails the provision of operational port services $[9,11,13,17-20]$.

\subsubsection{Ports Development and Administration in Nigeria}

The evolution of ports reforms in Nigeria dates back to the year 1906 [1]. At independence in 1960, the need for indigenization of port industry became very obvious. Ports were formerly addressed marine before its metamorphosis to Nigeria Ports Authority in 1954. The enactment of the NPA Act in 1954 was the first bold step 
adopting an integrated national approach to ports administration in Nigeria. It [21,22] identified eight major and other ancillary ports and jetties across the coastal areas in Nigeria. These ports include Lagos Port Complex; Apapa; Tin Island Port, Port Harcourt (old), Federal Ocean Terminal, Onne; Warri Port, Calabar Port, Koko Port and container Terminal Port, Lagos [23].

\subsubsection{Profile of Revenue Generation of Nigeria Ports Authorities (2010 - 2019)}

In an attempt to diversify the Nigerian revenue which was over $70 \%$ oil controlled, the federal government of Nigeria took certain steps to enhance the revenue generated from the maritime sector by changing the management and technology employed at the Nigerian ports authority [24,25]. It is [21] opined that in order to achieve the lofty ambition and target of huge revenue that will complement proceeds from oil sales, certain measures must be effected such as deployment of cutting edge technology and assist to ensure that all revenue leakages are blocked.

Consequent upon the revenue narration in the foregoing, the Nigerian Ports`sources of revenue generation could be categorized into two types namely, internally generated revenue (traffic revenue, harbor revenue and administrative revenue) and income from other sources (dividend on equity participation, rental port development levy, annual license fees and rents and rates from Cabotage activities).

\subsubsection{Revenue Performance of Port Authorities}

Port revenues are earned mainly from berth occupancy and cargo handling fees and it was noted that Port financial Performance apart from the traditional financial statements, may be determined by relating Ports income generation operating surpluses and expenditures to total GRT/NRT of shipping and the total tonnage of cargo handled at the port [26]. The useful measure of financial performance is the rate of return on turnover which is determined by dividing operating surplus by operating income.

\subsubsection{Economic Growth Measurement - Gross Domestic Product (GDP) of Nigeria}

Nigeria is one of the key regional players in West Africa with a population of approximately 202 million accounting for over half of the region's population size and one of the largest population of youths in the world [25].

\subsubsection{Gross Registered Tonnage}

This refers to record of internal volume (internal capacity) of ships or water going vessels used as a means for categorizing commercial vessels. 


\subsubsection{Total Tonnage of Cargo Handled (Throughput)}

Tonnage of cargo handled, otherwise called Port Throughput, and measures the amount of cargo or number of vessels the port authority handles overtime.

\subsection{Theoretical Review}

This paper is anchored on the modified neoclassical growth theory referred to as the endogenous growth theory. It could be termed as an economic ideology which operates within a closed system from other parts of the world. On the other hand, the modified neoclassical growth model assumes that economic growth is stimulated by both endogenous factors (government policies) and exogenous forces (technology, expert advices, capital, and amount of unskilled labor) [26].

\subsection{Empirical Review}

The study of the analysis of the impact of port operations in Nigeria using least square regression statistical techniques and concluded that gross registered tonnage of the vessel has significantly contributed to the Nigerian gross domestic product (GDP) [26]. In the study carried out by [27] on the Analysis of relationships between Ports activities and other sector of the economy using simple regression estimation techniques, it discovered that port activities resulted in an increase in fiscal revenue and accelerated economic growth. Using panel data regression, a research on Transportation Infrastructure and Economic Growth in China discovered that transportation networks have a positive effect on per capital growth rate across all sectors of the Chinese economy [28,29]. This position was further supported by [30].

However, inefficient port system was highlighted by [31] and corroborated by [32] which revealed that in Korea, the port cities of Busan and Icheen failed to get out of poor state of economic performances.

\section{Data and Methods}

The research design employed in this study is the ex-post factor approach, which entails the use of the output of already concluded events in assessing the performance of the Ports authorities under study. Secondary data were used and obtained from the Nigeria Ports Authority and the National Bureau of Statistics.

\subsection{Sample Study and Model Specification}

The sample adopted for this study is the Nigeria Ports Authorities with over 17 seaports in Nigeria and the relevant variables to measure the effect of the authorities' financial performance on the economic growth and development of Nigeria include the sectoral Gross Domestic Product (GDP), income generation operating surpluses and expenditures to total GRT/NRT of shipping and the total tonnage of cargo handled at the port. 
Using the [32] performance metrics, other relevant variable will include; Income (expenditure) per GRT which translates to Total Revenue (expenditure) divided by Total GRT (or NRT) of shipping; Operating surplus per ton of cargo handled is measured by Operating surplus divided by Total tonnage of cargo handled (throughput) while the Rate of return on turnover is measured by Operating surplus divided by Operating income.

Hence, using above theoretical analysis:

$$
\begin{gathered}
G D P=f(\text { TRGRT, OSTP,OSOI }),[\%] \\
G D P=a_{0}+a_{1} \text { TRGRT }+a_{2} \text { OSTP }+a_{3} \text { OSOR }+U_{t},[\%] \\
\text { TRGDP }=a_{0}+a_{1} \text { TRGRT }+a_{2} \text { OSTP }+a_{3} \text { OSOR }+U_{t},[\%]
\end{gathered}
$$

where: GDP is Gross Domestic Product contribution [\%]; TRGDP is Total Port Revenue to Gross Domestic Product [\%]; TRGRT is Total Revenue to total gross registered tonnage [\%]; OSTP is Operating surplus (Ports) to total tonnage of cargo handled (Throughput) [\%]; OSOR is Operating Surplus to Operating Revenue of the ports authorities [\%]; $a_{0}-a_{3}$ are Parameters [-]; $U_{t}$ is Error term.

\subsection{Apriori Expectation}

From studies, we expect a positive correlation between the contributions to GDP and the relevant financial parameters $[26,32]$.

\section{Results}

Table 1 and 2, shows TRGDP, Revenue contribution to GDP of $29.73 \%$ in 2010. The revenue parameters show that the economic recession that hit the country between 2017 and 2018 also affected the maritime sector adversely. The revenue of the ports authority to the nation's GDP stood at an average of between $32 \%$ to $45 \%$ between 2010 to 2016, before the sharp growth to $70.69 \%$ in 2017 and then drop to $62.18 \%$ by 2019. The rise in this index (Total revenue to GDP indicates that the recession strongly affected the key economic drivers such as oil prices, while the maritime sector helped to cushion this adverse effect during the period). 
Table 1 NPA performance data 1. Source: [33,34]

\begin{tabular}{lllllll}
\hline Year & $\begin{array}{l}\text { Amt.Realize } \\
\text { d (TR) } \\
\text { ('Million) }\end{array}$ & $\begin{array}{l}\text { Amt.Expe. } \\
\text { (TE) } \\
\text { ('Million) }\end{array}$ & $\begin{array}{l}\text { Amt. } \\
\text { Remitted } \\
\text { (OS) } \\
\text { ('Million) }\end{array}$ & $\begin{array}{l}\text { GDP } \\
\text { Contrib. } \\
\text { ('Million) }\end{array}$ & $\begin{array}{l}\text { GRT } \\
\text { ('Million) }\end{array}$ & $\begin{array}{l}\text { Throughput } \\
\text { ('Million) }\end{array}$ \\
\hline 2010 & 101,050 & 95,030 & $6,020.0$ & 339,848 & 106.6896 & 76.744727 \\
\hline 2011 & 115,020 & 105,140 & $9,880.0$ & 374,099 & 122.6147 & 83.461697 \\
\hline 2012 & 136,010 & 125,200 & $10,810.0$ & 405,441 & 129.5069 & 77.104738 \\
\hline 2013 & 157,310 & 144,140 & $13,170.0$ & 514,966 & 138.6722 & 78.281634 \\
\hline 2014 & 172,800 & 154,770 & $18,030.0$ & 568,499 & 156.0714 & 84.951927 \\
\hline 2015 & 177,200 & 158,770 & $18,430.0$ & 481,066 & 144.6152 & 77.387638 \\
\hline 2016 & 182,420 & 158,550 & $23,870.0$ & 404,650 & 139.4065 & 70.819092 \\
\hline 2017 & 265,600 & 255,290 & $10,310.0$ & 375,745 & 137.4802 & 71.903266 \\
\hline 2018 & 270,560 & 245,910 & $24,650.0$ & 398,186 & 128.6718 & 73.175127 \\
\hline 2019 & 277,680 & 248.9600 & $28,720.0$ & 446,543 & 131.8975 & 74.698136 \\
\hline
\end{tabular}

Table 2 performance data 2. Source: authors

\begin{tabular}{ccccc}
\hline YEAR & OSTP & TRGRT & OSOR & TRGDP \\
\hline 2010 & 78.442 & 947.140 & 0.05957 & 0.29734 \\
\hline 2011 & 118.378 & 938.060 & 0.08590 & 0.30746 \\
\hline 2012 & 140.199 & 1050.214 & 0.07948 & 0.33546 \\
\hline 2013 & 168.239 & 1134.402 & 0.08372 & 0.30548 \\
\hline 2014 & 212.238 & 1107.186 & 0.10434 & 0.30396 \\
\hline 2015 & 238.152 & 1225.321 & 0.10401 & 0.36835 \\
\hline 2016 & 337.056 & 1308.547 & 0.13085 & 0.45081 \\
\hline 2017 & 143.387 & 1931.915 & 0.03882 & 0.70686 \\
\hline 2018 & 336.863 & 2102.714 & $0 . .09111$ & 0.67948 \\
\hline 2019 & 384.481 & 2105.271 & 0.10343 & 0.62184 \\
\hline
\end{tabular}

\subsection{Stationarity Tests}

The test for stationarity requires that the variables in the series model must be stationery at a given level and p-value must be significant at that level. Stationerity is attained where the test statistics is most negative and greater than the critical value of the chosen level of significance.

Table 3 Stationarity table. Source: authors

\begin{tabular}{ccccc}
\hline Variable & ADF t-statistics & $\begin{array}{c}\text { Critical value } \\
\text { @ 5\% }\end{array}$ & P-value & $\begin{array}{c}\text { Level of } \\
\text { integration }\end{array}$ \\
\hline TRGDP & -3.3665 & -2.0063 & 0.0050 & $\mathrm{I}(2)$ \\
\hline TRGRT & -3.6094 & -2.0063 & 0.0034 & $\mathrm{I}(2)$ \\
\hline OSTP & -3.8539 & -2.0212 & 0.0030 & $\mathrm{I}(2)$ \\
\hline OSOR & -2.9196 & -2.0440 & 0.0130 & $\mathrm{I}(2)$ \\
\hline
\end{tabular}


From the table 3, all the variables were found to be stationery at order two (2). At the second difference as reported, the ADF Statistics for the respective variables were more negative than the critical values at 5\% significance level.

\subsection{Heteroskedasticity Tests}

If the variance of the errors is not constant, we test for the presence of heteroskedasticity with the intention of treating same if found. The treatment method used is the ARCH test (Autoregressive conditionally Heteroskedastic). The Null hypothesis states that there is no Heteroskedasticity if the p-value is greater than the level of significance [35].

Table 4 Heteroskedasticity table. Source: authors

\begin{tabular}{cccc}
\hline Heteroskedasticity Test: ARCH & & \\
\hline F-statistic & 0.156761 & Prob. F(1,4) & 0.7124 \\
\hline Obs*R-squared & 0.226273 & Prob. Chi-Square(1) & 0.6343 \\
\hline
\end{tabular}

In the case of table 4, we accept the Null hypothesis that there is no evidence of heteroskedasticity since p-value is greater than $5 \%$ of the significance level.

\subsection{Regression Tests}

Hence, from table 5, TRGRT(1) at led 1, it has a t-statistic value of 4.9744 and a p-value of 0.0156 was found to have a positive effect on Total Revenue to Gross Domestic Product and this effect is statistically significant at 5\% level since its p-value is well below 0.05. Therefore, we reject null hypothesis to accept the alternative. Similarly, Operating surplus to total revenue, OSOR showed a t-statistic value of -6.7531 and a p-value of 0.0066 is negative, but it has a statistically significant effect on total revenue to gross domestic product since its p-value is below 5\%. However, the OSTP(-1) at lag 1, has a t-statistic value of 0.8559 and p-value of 0.4549 and this effect is positive and statistically not significant at the $5 \%$ level.

Table 5 Regression table. Source: authors

\begin{tabular}{|c|c|c|c|c|}
\hline \multicolumn{5}{|c|}{ Dependent Variable: TRGDP } \\
\hline \multicolumn{5}{|c|}{ Method: Least Squares } \\
\hline Variable & Coefficient & Std. Error & t-Statistic & Prob. \\
\hline $\mathrm{C}$ & 0.191756 & 0.042043 & 4.560948 & 0.0198 \\
\hline TRGRT (1) & 0.000248 & 4.9805 & 4.974443 & 0.0156 \\
\hline OSTP $(-1)$ & 0.000216 & 0.000253 & 0.855946 & 0.4549 \\
\hline OSOR & -2.053840 & 0.304135 & -6.753058 & 0.0066 \\
\hline R-squared & 0.990857 & \multicolumn{2}{|c|}{ Mean dependent var } & 0.396911 \\
\hline Adjusted R-squared & 0.981713 & \multicolumn{2}{|c|}{ S.D. dependent var } & 0.146382 \\
\hline F-statistic & 108.3680 & \multicolumn{2}{|c|}{ Durbin-Watson stat } & 1.924644 \\
\hline Prob (F-statistic) & 0.001480 & & & \\
\hline
\end{tabular}




\subsection{Co-integration Tests}

The Engle-Granger Co-integration tests was carried out on the model and the result is shown in table 6:

Table 6 Engle-granger co integration. Source: authors

\begin{tabular}{|c|c|c|}
\hline \multicolumn{3}{|c|}{ Co-integration Test - Engle-Granger } \\
\hline \multicolumn{3}{|c|}{ Specification: TRGDP TRGRT(1) OSTP(-1) OSOR C } \\
\hline \multicolumn{3}{|c|}{ Co-integrating equation deterministics: $\mathrm{C}$} \\
\hline \multicolumn{3}{|c|}{ Null hypothesis: Series are not cointegrated } \\
\hline & Value & Prob.* \\
\hline Engle-Granger tau-statistic & -2.621741 & 0.6639 \\
\hline Engle-Granger z-statistic & -6.334353 & 0.4058 \\
\hline
\end{tabular}

The result of the Engle-Granger co-integration tests in table 6 shows that there is no co-integration between the dependent variable, TRGDP and the independent variables - TRGRT, OSTP and OSOR at the 0.05 level of significance as both the Engle-Granger tau-statistic and Engle-Granger z-statistic showed insignificant effect of the independent variables on the dependent variable (TRGDP) of 0.6639 and 0.4058 , respectively.

\section{Discussion}

The table 5, TRGRT(1) at led 1, has a t-statistic value of 4.9744 and a p-value of 0.0156 , it was found to have a positive effect on Total Revenue to Gross Domestic Product and this effect is statistically significant at 5\% level since its p-value is well below 0.05. Therefore, we reject null hypothesis to accept the alternative. Similarly, Operating surplus to total revenue, OSOR showed a t-statistic value of -6.7531 and a p-value of 0.0066 is negative, but has statistically significant effect on total revenue to gross domestic product since its p-value is below $5 \%$.

However, the OSTP (-1) at lag 1, has a t-statistic value of 0.8559 and p-value of 0.4549 and this effect is positive and statistically not significant at the $5 \%$ level. The implication of this result is that a $1 \%$ increase in TRGRT (Total Revenue to total gross registered tonnage) will result to a $0.00248 \%$ increase in TRGDP and the coefficient of the future level of TRGRT variable has a positive sign and is positive at the 5\% significance level. This supports the view that the future level of Total Revenue to Gross Registered Tonnage (TRGRT) in Nigeria positively affects economic growth measured by total revenue to Gross Domestic Product (TRGDP) in the shortrun.

The result evidently shows that both total revenue to total registered tonnage and operating surplus to operating/total revenue have significant effect on economic growth measured by total revenue to gross domestic product of Nigeria in the short-run, the formal having positive effect while the latter carried a negative effect; hence, policy makers should pay close attention to factors that affect these variables in managing the NPA and the Nigeria maritime sector. It was found, however, that operating revenue surplus to throughput (i.e. total tonnage of cargo handled) had no significant effect on TRGDP for the NPA. 
While the result of the effect of TRGRT and OSOR on TRGDP corroborates with the findings of [36,37]; the result of OSTP, however, did not agree with the findings in [26] as it showed a statistically insignificant effect on TRGDP (Total Revenue to Gross Domestic Product). Also, the research revealed no co-integration between TRGRT, OSTP and OSOR on economic growth (TRGDP). This is very revealing, as it implies that the result of recent port reforms by the NPA have not been effective in addressing a sustainable incremental long-term revenue capacity of the agency. Another plausible explanation could be that the reform needed more time for review.

\section{Conclusion}

This paper studied the effect of Port Revenue Performance on Economic Growth; The Nigerian Ports Authority Experience (2010-2019). The study discovered that revenue performance and economic growth have positive and significant relationship when revenue is assessed using revenue generated to gross registered tonnage and gross domestic product. We also observed a similar effect of operating surplus to total revenue, which was negative but significant. But for the total revenue to throughput, we observed that there was no significant relationship. Hence, we conclude that Port Revenue measured by revenue generated by the ports and registered gross tonnage have positive and significant effect on economic growth while the total revenue to the throughput have insignificant effect.

Based on the outcome of this research, we recommend as follows:

1. Policy makers are admonished to formulate appropriate and implementable regulatory framework that will address infrastructural deficits at the ports and stimulate port utilization by established major foreign vessel companies. This expectedly will result to increased registration fees, annual license fee for cabotage vessel financing fund and port charges as more major vessels will call on the ports regularly.

2. The government is advised to embark on dredging and expansion of our existing inland waterways to attract more vessels to the ports and generate increased cargo handling and other related fees such as harbor revenue, administrative revenue and traffic revenue.

\section{Acknowledgement}

We appreciate the management and principal officers of the Nigeria Maritime University for the platform to service in the institution. We hereby confirm that we did not receive any financial support or sponsorship from any organization.

\section{References}

[1] Crown, A. (2017). 25 Years Port Development, Master plan. Final Report. NPA Study (041 NPA CA) Crown Reference No. 106890. 
[2] Obioma. R.N., Ikechukwu A.D., Musa, M., Victor, O. \& Shehu, U.G. (2016). Project Infrastructure Management and Economic Concessioning on Nigeria`s Economic Growth (A Focus on Delta Port). International Journal of Business and Applied Social Science 2(4).

[3] Chin, A. \& Tongzon, J. (1998). Maintaining Signapore as a major shipping and air transport hub. In: Toh, T. (Ed.), Competitiveness of the Signapore Economy, (pp. 83-114). Signapore University press, Signapore.

[4] Tongzon, J. \& Heng, W. (2005). Port Privatization, efficiency and competitiveness: Some empirical evidence from container ports (terminals). Transportation Research Part A: Policy and Practice, 39(5), 405-424.

[5] Jerome, A. (2008). Privatization and enterprise performance in Nigeria: case study of some privatized enterprises. AERC Research paper 175, Nairobi. African Economic Research Consortium.

[6] Razak, R. (2005). Understanding Port reforms. The Nigerian Situation (Ed). Lagos: Marine Business International.

[7] Everett, S (2007). Port reform in Australia; regulation constraints on efficiency, Marit. Pol. Mgmt. 34(2), 107119.

[8] Robinson, R. (2007). Regulating efficiency into port-oriented chain systems: export coal through the Dalrmple Bay terminal, Austrial, Marit. Pol. Mgmt 34(2), 89-106. The NPA Act (1954) as Amended

[9] Goss, R. O. (1990). Economic Policies and seaports: are ports authority necessary, Marit. Pol.Mgmt., 17, (4), 257-271.

[10] Debrie, J., Lavaud-Letilleul, V. \& Parola, F. (2013). Shaping port governance: the territorial trajectories of reform. Journal of Transport Geography 27, 56-65.

[11] Notteboom, T., De Langen, P. \& Jacobs, W. (2013). Institutional Plasticity and path dependence in seaports: Interactions between institutions, port governance reforms and port authority routines. Journal of Transport Geography 27, 26-35.

[12] Brooks, M. R. \& Cullinane, K. (2006). Devolution, port governance and port performance. Elsevier, Amsterdam 17.

[13] Van der Lugt, L.M., Langen, P. W. \& Hagdorn, L. (2015). Beyond the landlord: Worldwide empirical analysis of port authority strategies. International Journal of Shipping and Transport Logistics 7(5), 570-596.

[14] De Langen, P.W. \& Heij, C. (2014). Corporatization and performance: a literature review and an analysis of the performance effects of the corporatization of port of Rotterdam authority. Transport Reviews 34(3), 396414.

[15] Baird, A.J. (2002). Privatization trends at the world's top-100 container ports, Maritime Policy \& Management 29(3), 271-284.

[16] Verhoeven, P. (2010). A Review of Port Authority Functions: Towards a Renaissance? Maritime Policy and Management 37(3), 247-70.

[17] Robinson, R. (2002). Ports as elements in value-driven chain systems: the new paradigm. Maritime Policy \& Management 29(3), pp 241-255.

[18] Notteboom, T. \& Rodrigue, J.P. (2005). Port regionalization: towards a new phase in port development. Maritime Policy and Management 32, 297-313.

[19] De Langen, P. W. \& van der Lugt, L.M. (2017). Institutional reforms of port authorities in the Netherlands; the establishment of port development companies. Research in Transportation Business \& Management 22, 108113.

[20] Moya, M.J. \& Valero, F.M. (2017). Port choice in Container market. a literature review 37(3), 300-321

[21] NPA (2018). NPA Handbook.

[22] Okerefe, C.O. (2018). Abc OF Shipping and Ports Operation in Nigeria. Stepcrraft Books, Ogudu Rd, Ojota, Ogudu Lagos, Nigeria.

[23] Idornigie, P.O. (2006). Designing, negotiating and drafting of concession contracts Abuja; Brueau of Public Enterprise.

[24] This Day. (2016). NPA Revenue Performance. Retrieved 2019

[25] World Bank. (2019). Transportation and Water Resources. Working Papers 
[26] Omoke, V., Aturu A.C., Nwaogbe O. R., Ajiboye, A.O. \& Diugwu, I. (2019). Analysis of the impact of Port Operations on Nigeria Economy: A Focus on Apapa Seaport.

[27] Essoh, N. (2013). Analysis of Relationship between Port Authority and other Sectors of the Economy: Evidence from Cote d'ivoire. American Journal of Industrial and Business Management 3, 357-366.

[28] Banerjee, E. (2009). Access to Transportation Infrastructure and Economic Growth in China. MacArthur Network for Inequality Conference in Beijing.

[29] Sleeper, D.M. (2012). Port Significance: Contributions to Competiveness in Latin America and Asia. J. Global Business Community 3(1), 22-28.

[30] Ziaul, H.M. \& Hans-Joachim. S. (2018). The Impacts of Port Infrastructure and Logistic Performance on Economic Growth: the Mediating Role of Seaborne Trade. J Shipping and Trade 3.

[31] Clark, X.D. \& Micco. (2004). Port Efficiency, Maritime Transport Cost and Bilateral Trade. J Dev Econ 75(2), 417-450.

[32] World Bank. (1993). Port Performance Indicators. Transportation, World Bank Journal of Transportation, Water and Urban Development Ps-6 (as cited by Kek Choo Chung, 1993)

[33] Brooks, C. (2014). Introductory Econometrics for Finance (3rd edition), Cambridge University Press, London, UK.

[34] Sjafrizal, E. (2008). Ekonomi regional. teori dan aplikasi, Baduose Media, Praninta Offset, Padang Sumatera Barat.

[35] NPA. (2019). Annual Reports and Accounts

[36] World Bank. (2014). Transportation and Water Resources. Working Papers

[37] National Bureau of Statistics. (2019). Nigerian Ports Authority Revenue Performance Report, 2010-2019. 